\title{
INSANITY AS A DEFENCE IN CRIMINAL LAW THE MEDICAL VIEW
}

\author{
By A. D. MacPherson, M.D., \\ Medical Superintendent of Provincial Mental Institute \\ at Edmonton
}

The legal definition of insanity is based on the MNaghten Rulings, ${ }^{1}$, which state: (1) "Every man is to be presumed to be sane, and to possess a sufficient degree of reason to be responsible for his crimes, until the contrary be proved to [the jury's] satisfaction ..." (2) "To establish a defence on the ground of insanity, it must be clearly proved that at the time of committing the act, the accused was laboring under such a defect of reason, from disease of the mind, as not to know the nature and quality of the act . . . or if he did know it, that he did not know he was doing what was wrong." (3) [With tegard to] "persons who labor under such partial delusions only, and are not in other respects insane, we are of the opinion that, notwithstanding the party accused did the act complained of with a view, under the influence of insane delusion, of redressing or revenging some supposed grievance or injury, or of producing some public benefit, he is nevertheless punishable according to the nature of the crime committed, if he knew at the time of committing such crime that he was acting contrary to law ..."

For a considerable time there have been arguments about these rulings, not only between the legal and medical professions, but also between members of the same professions, and there has been a recent Royal Commission, including members of both professions, which has gone into the problem extensively. The arguments which arise are mainly due to the great changes in psychiatry, which was developed in recent years.

A literal interpretation of point (2) above would rule as insanity only certain disturbed states, such as acute mania, acute schizophrenic episodes, postepileptic confused states, senile deterioration, some forms of delirium tremens, low-grade defectives, and a few very unusual confused conditions. It would eliminate nearly all types of upset characterized by delusional ideas and persons with hallucinations. Uinfortunately, this group make up the greater percentage of mental illness, and nearly all such cases have some conception of the nature - and quality of their acts and realize what is considered wrong; but they believe that they are justified because of their delusions. These people clearly demonstrate that they know what they are doing by in many cases doing a considerable amount of detailed planning in order to carry out the crimes. It is this type of case which appears to produce the greater number of arguments. For example, a man believes that his neighbours are poisoning his well water, that they are using peculiar rays at night in order to produce physical symptoms in him, with some idea, not clearly defined in his mind, of trying to get rid of him in order to occupy his farm. Finally, as a result of these ideas, he shoots the 
neighbour. There is no doubt that he knows what he is doing and that he knows that it is wrong, but he considers he is justified.

Or, for example, take another case, where a hired man left his job because he thought that his employer looked at him "peculiarly". For the next two years this man wandered about the province but was unable to hold a job for any length of time because of his preoccupation about his former employer. He then developed the idea that the employer was following him about the country, telling people stories about him, and so making it impossible for him to hold a job. He finally returned to his former district and in a very skilful manner ambushed his employer. Again, there is no doubt that he knew fully what he was doing and that it was considered wrong, but he too felt that he was justified in ending his persecution.

The third case is that of a man with auditory hallucinations. Voices told him that his neighbors were devils and that he should kill them. Finally, as a result of this, he shot one of his best friends. Although he was greatly perturbed about this and felt he was wrong, he did obey the voices.

Although people such as the above are quite in touch with their surroundings, and are more or less able to carry on their daily activities and can carry on rational conversations, the fact that their delusional ideas are so clear and so fixed is evidence that their thinking processes are so disordered that they are very seriously ill mentally, and no one would consider them mentally competent. No member of the medical profession would hesitate to say that such individuals are insane and dangerous to be at large, and I doubt that any judge or magistrate would consider them to be sane.

The M'Naghten ruling does, in effect, make a sort of provision to deal with these cases: "If under the influence of his delusion he supposes another man to be in the act of attempting to take away his life, and he kills that man, as he supposes, in self-defence, he would be excmpt from punishment. If his delusion was that the deceased had inflicted a serious injury to his character and fortune, and he killed him in revenge for such a supposed injury, he would be liable to punishment." Thus the man in the first case mentioned before, believing that his life was in danger, would be exempt from punishment, but the other two would not.

Generally speaking, what happens to cases of this type, in this province at least, is that such persons are declared to be mentally ill to the point where they are not fit to stand trial, and they are admitted to a mental hospital under what was formerly section 970 and is now section 527 of the revised Criminal Code of Canada.

In actual practice, in this province, not too much difficulty exists with regard to this group of patients. What usually happens is that the accused is referred for psychiatric examination, either on the recommendation of the police, due to odd features in the way that the crime was committed, or due to his behaviour while under arrest; or on the recommendation of the Crown prosecutor, the defence counsel, or by the magistrate himself, after his consid. eration of the evidence. If such an examination shows that the man is mentally 
ill to a degree where he is considered to be insane from a medical viewpoint, a recommendation is made to the Attorney-General's department that the accused be admitted to a mental hospital, under section 527.

In cases of homicide, it is our practice to ask the Attorney-General to appoint, in addition, a private psychiatrist to examine the patient independently in order to obtain a supporting opinion. The end result is the same in that the accused ends up in custody, except that he is held in a mental hospital rather than in the penitentiary. This usually works out to the disadvantage of the accused in that his detention in a mental hospital is more likely to be permanent than if he served a definite sentence. What might eventually happen in these cases varies. If the accused does not recover he, of course, stays permanently in a mental hospital. If he should recover to the point where he is fit to stand trial, he would then have to return to court, and his defence would prob. ably be that he was insane at the time the crime was committed. He would, in all probability, be found "not guilty" because of insanity, and "to be further detained at Her Majesty's pleasure".

Another point to discuss, and one which leads to much disagreement, is that of the status of the accused who is said to be "emotionally unstable". While most psychiatrists believe that the emotionally unstable person is not insane, there is a fairly large group, psychoanalytically inclined, who contend that, while these pepole are sane under the M'Naghten ruling, their lack of emotional control more or less relieves them of responsibility for their act. To accept this is, I think, a dangerous precedent in that it could serve as a very easily available defence in many cases where such defence is not justifiable, and it would make the court the scene of pointless arguments.

The third point of argument is the so-called "irresistible impulse". Many mentally ill people do commit impulsive actions, but there are always many other symptoms which justify a diagnosis of insanity. One meets the defence of "irresistible impulse" most commonly in cases where there are no other symptoms of insanity, where the excuse of irresistible impulses is the only defence where there is at least a partial motivation, and where there is no previous history. While some psychiatrists would claim that this is evidence of insanity, I think most psychiatrists and most members of the legal profession will deny this.

Another defence which often leads to disagreement is that of "blackouts" or amnesic periods, and strange to say, more members of the legal profession seem to accept this form of defence than do members of the medical profession. Where there is a history of such "blackouts" previously, they should have appeared serious enough to warrant medical investigation and treatment of the patient. Under such circumstances, I can see its being evidence of some form of insanity, although it is often extremely difficult to make a diagnosis in such states. However, if the "blackouts" occur only if they are of benefit to the accused, then it sounds too implausible to be acceptable without further proof.

The above briefly mentioned conditions, namely instability, irresistible impulses, "blackouts" and amnesia, are rarely used if any other defence is available. They are rarely supported by reliable evidence, but they are very difficult 
to disprove. It is in situations of this kind that there are likely to be two sides among the psychiatrists, one side arguing that the case is white and the other side that it is black, with two competent sets of lawyers supporting the opposing arguments.

It is when this condition arises that I think we have to adhere most closely to the M'Naghten ruling. Otherwise it would be very difficult to convict a great many people who should be convicted, for it is easy for an intelligent person with some knowledge of mental illness to give a very impressive account of his symptoms.

The psychopathic personality presents another problem. It is extremely rare that such individuals are insane in the generally accepted sense, either medically or legally. But there is a very definite section of psychiatric opinion, especially among those belonging to the 100 per cent psychoanalysis school, who believe that such people should be considered insane. The argument here really lies between two viewpoints in psychiatty, rather than with the law.

A furcher case of misunderstanding lies in the legal atcitude towards a case. The medical profession sees the accused as a patient, and considers all his reactions and ideas, whereas the legal profession is generally concerned solely with the guilt or iniocence in the given case. This leads to the medical profession's being accused of being too sympathetic. There may be cases where this accusation is justified. Medical opinion should be, and usually is, completely unbiased, and is concerned only with giving the court as expert an opinion as possible of the patient's mental state.

In this province the differences between the two professions concerning the question of insanity are theoretical rather than practical. The main point of difference, as mentioned above, is centred about mental illness of the delusional type. In practice, both professions generally agree as to the conclusions and the disposal of the cases. Arguments as to the other forms of defence will continue to exist as long as there are divergent psychiatric viewpoints.

Some points which have arisen from my experience when I have served from time to time as expert witness might be of interest, although they do not properly come under the title of the paper.

Many a counsel will ask: "How many times did you examine this man?" or "How many hours did you spend in examining him?" This is of relative unimportance. No physician would care to give expert evidence unless he was, himself, satisfied that he had done a thorough examination, and the amount of time necessary for such an examination varies markedly from case to case.

In Edmonton, at least, there has been very little difference in psychiatric opinion. Most of us have come to the same general conclusions in regard to the cases seen. Perhaps we have been favored in that we have been largely free from biased or "persuaded" expert opinion testimony.

${ }^{1} M$ 'Naghten's Case (1843), 10 C. Gin. 200; 8 E.R. 718; 4 State Tr. N.S. 847; Town St. Tr. 314; 1 Car. 2 Kir. 130, n; sub nom. Insane Criminals, 8 Scott, N.R. 595.

${ }^{2}$ All three quotations are by Lord Chief Justice Tindal, $10 \mathrm{Cl}$. Fin. 200 at pp 209.10; 8 E.R. 718 at p. 722 .

${ }^{3} 10$ C. \& Fin. 200 at p. 211; 8 E.R. 718 at p. 723. 